\title{
Prospects and Frontiers of Stem Cell Toxicology
}

\author{
Shuyu Liu,,2 Nuoya Yin,, ${ }^{1,2}$ and Francesco Faiola ${ }^{1,2}$
}

The development of stem cell biology has revolutionized regenerative medicine and its clinical applications. Another aspect through which stem cells would benefit human health is their use in toxicology. In fact, owing to their ability to differentiate into all the lineages of the human body, including germ cells, stem cells, and, in particular, pluripotent stem cells, can be utilized for the assessment, in vitro, of embryonic, developmental, reproductive, organ, and functional toxicities, relevant to human physiology, without employing live animal tests and with the possibility of high throughput applications. Thus, stem cell toxicology would tremendously assist in the toxicological evaluation of the increasing number of synthetic chemicals that we are exposed to, of which toxicity information is limited. In this review, we introduce stem cell toxicology, as an emerging branch of in vitro toxicology, which offers quick and efficient alternatives to traditional toxicology assessments. We first discuss the development of stem cell toxicology, and we then emphasize its advantages and highlight the achievements of human pluripotent stem cell-based toxicity research.

Keywords: stem cell toxicology, developmental toxicity, pluripotent stem cells, in vitro toxicology, embryonic stem cells

\section{Introduction}

$\mathrm{T}$ OXICOLOGY, THE STUDY of the adverse effects of chemicals on living organisms, serves human society in many ways, to not only protect humans and the environment from the deleterious effects of toxicants but also facilitate the development of safer chemicals to be employed as clinical drugs, pesticides, food additives, and so on. Toxicity can be acute or chronic, comes from different routes of exposure, varies from one organ to another, as well as yields to different outcomes according to age, genetic background, gender, diet, physiological conditions, and the health status of the organism.

Many in vivo and in vitro testing methods are available in toxicology. Although animal tests have played a critical role in toxicology, a trend for an alternative in vitro toxicology, mostly consistent in cell-based assays, started in the 1950s with the publication of the 3R principle (Replacement, Reduction, and Refinement) [1]. In fact, in vitro toxicity tests take advantage of well-developed cell culture protocols and pre-validated cell-based toxicity tests with multiple biological endpoints. Besides, cell-based toxicity tests usually require shorter time and still allow for more replicates, than in vivo assays do [2].

Currently, the list of potentially hazardous chemicals we can get exposed to is continuously and rapidly updated, due to the exponential discovery and production of artificial materials. Therefore, it is extremely urgent to develop highthroughput experimental systems that will let us screen for the potential toxicity of all these substances.

Hence, in this review, we introduce stem cell toxicology, an emerging branch of in vitro toxicology, which offers effective and efficient alternatives to traditional toxicology assessments. We first discuss the development of stem cell toxicology, and then emphasize its advantages and highlight the achievements of human pluripotent stem cell (hPSC)based toxicity research. We hope this review will be inspiring and innovative, and nurture more efforts into stem cell-based toxicology research.

\section{Development of Stem Cell Toxicology}

Stem Cell Toxicology, originally inspired by the mouse embryonic stem cell test (EST), includes toxicology research on stem cells and stem cell-derived differentiated cells. Stemness allows for in vitro cell maintenance for many generations without loss of differentiation potential and without genetic manipulations. Moreover, contrary to somatic or cancer cells, stem cell-based toxicity models let us perform developmental toxicity assays, in particular with mouse pluripotent stem celland hPSC-based models. Therefore, those unique advantages of

\footnotetext{
${ }^{1}$ State Key Laboratory of Environmental Chemistry and Ecotoxicology, Research Center for Eco-Environmental Sciences, Chinese Academy of Sciences, Beijing, P.R. China.

${ }^{2}$ College of Resources and Environment, University of Chinese Academy of Sciences, Beijing, P.R. China.

(C) Shuyu Liu et al. 2017; Published by Mary Ann Liebert, Inc. This is an Open Access article distributed under the terms of the Creative Commons Attribution License, which permits unrestricted use, distribution, and reproduction in any medium, provided the original work is properly cited.
} 
stem cell-based toxicity models call for further development and utilization of this new crossover field.

\section{Mouse stem cell-based toxicology}

After the successful derivation of mouse embryonic stem cells (mESCs) [3] and induction of mouse-induced PSCs (iPSCs) [4], the rapid development of stem cell technology also allowed for mESC-based toxicology research.

The first toxicity test based on mESCs was designed to test the cytotoxicity of potential teratogens [5]. It not only showed overall consistent results with in vivo data but also suggested that mESCs were more sensitive to tested chemicals, compared with mouse fibroblasts [5]. After this encouraging attempt, the mouse EST was proposed as the first complete and accepted in vitro toxicity test and has been continually improved and refined ever since [6]. The original EST consisted of, on 10-day toxicant exposure, MTT cytotoxicity assays on D3 mESCs and 3T3 mouse fibroblasts for the detection of IC50s (half maximal inhibitory concentrations), as well as a cardiogenic differentiation test with $\mathrm{D} 3 \mathrm{mESCs}$, to determine the ID50 (the equivalent of IC50 for differentiating cells) [6].

Several efforts have been addressed to the optimization of the EST, particularly regarding its efficiency in experimental operation, accuracy, and objectiveness of endpoint determination [7], as well as toward high-throughput applications and extensive utilization (the main refinements of the mESC-based EST are summarized in Table 1). One early improvement was the introduction of molecular endpoints for gene and protein expression. For instance, the expression of the cardiac marker myosin heavy chain, quantified by flow cytometry, helped judge to which extent cardiogenesis was affected by tested chemicals [26-28] in a more objective and accurate way, compared with the original scoring of beating clusters of cardiomyocytes by microscopic observation [6]. In another example, groups of genes representative of the whole genome and that were involved in toxicity responses were selected for more predictive, reliable, and yet less laborious assays [10,20,29]. More recently, a shortened EST based on the detection of the cardiac and neural crest Handl gene expression, through a luciferase reporter assay, showed good reproducibility [22]. In addition, studies on the effects of flusilazole and monophthalates on mESC cardiogenesis convinced that low chemical concentrations, although not cytotoxic, compromised mESC cardiogenesis by downregulating the expression of related genes in a dose-dependent manner $[20,30]$. These refinements allowed for the investigation of the underlying molecular events triggered by chemical exposure, especially for changes in molecular levels that could be relevant for development, instead of merely cell viability.

Another major strategy to improve the original EST has taken advantage of differentiation procedures besides cardiogenesis, such as neural differentiation, endothelial differentiation, and osteogenesis. Such strategies were motivated by the fact that in some cases the traditional EST underestimated the possibility that different developmental lineages might show different responses on exposure to the same chemicals $[8,14,31]$. The use of cardiogenic induction as the only differentiation procedure would not provide a comprehensive toxicity assessment. Therefore, to address this concern, the neural EST was introduced and successfully validated with six classical neurotoxicants with diverse mechanisms of toxicities [16]. Similar refinements were obtained by other groups
$[13,29,32]$. There were also EST-inspired tests based on the differentiation of mESCs into endothelial cells [33] and osteoblasts [14,31], which showed to be effective and responsive to novel embryotoxic compounds [33], strongly validating the choice of using additional differentiation protocols in the EST.

Currently, mESC-based toxicity assays represent a powerful tool for the high-throughput toxicity screening of emerging organic chemicals [25], for chemical use and exposure guideline purposes. For instance, the US Environmental Protection Agency (EPA) and others developed a toxicity assay based on the monolayer differentiation of mESCs into cardiomyocytes, called mESC adherent cell differentiation and cytotoxicity (ACDC) assay [34], enabling the high-throughput screening of environmental pollutants, which also gives information on the underlying molecular mechanisms [35].

\section{Human stem cell-based toxicology}

Both mESCs and human ESCs (hESCs) are necessary for stem cell toxicology research, but with different roles. In the perspective of stem cell biology, hESCs differ from mESCs in not only their morphology and expression of surface antigens but also gene markers and cytokines [3,36,37]. In addition, when derived from the inner cell mass of the blastocyst, mESCs are generally in the naive state (the highest pluripotency level) whereas hESCs are in the primed state (a lower pluripotency level) [38]. Thus, a rational corollary of these differences is that in toxicological terms, hESCs may be more appropriate than mESCs in terms of the representation of toxicity effects toward humans. In addition, hESC-based toxicity tests may be more reliable and indicative, since they avoid interspecies differences. Studies have found out hESCs were more sensitive to the adverse effects of a broad range of chemicals [39-42], and could be impaired by certain chemicals that were not necessarily toxic to mice, such as thalidomide [43], or chemicals, including ethanol and caffeine, which have raised health concerns $[44,45]$.

The first hESC-based toxicity tests took advantage of the neuronal induction from hESCs. Exposure of hESC-derived neurons to specific dopaminergic neurotoxins resulted in apoptotic cell death, production of reactive oxygen species, and loss of neuronal functions [46]. Two years after this study, the European Center for the Validation of Alternative Methods (ECVAM) proposed the establishment of the human EST [47]. In this case, H1 hESCs and hMRC-5 embryonic lung fibroblasts were exposed to two well-known developmental toxicants, all-trans retinoic acid (RA) and 5-fluorouracil (5-FU), for either 4 or 10 days. MTT cytotoxicity tests and gene expression analyses for cardiogenic markers demonstrated that the toxic responses caused by RA and 5-FU were compatible with previous in vivo data. These two studies demonstrated already that hESCs could be employed in cytotoxicity, developmental toxicity, and functional toxicity assays.

To assess the vulnerability of the human nervous and cardiovascular systems, neonatally and postnatally, hESC- or human iPSC (hiPSC)-based toxicity research has been embraced with a variety of artificial chemicals, such as bisphenol A, perfluorooctane sulfonate, trichloroethylene, trimethyltin chloride, ibuprofen, and paraquat [48-50], as well as more complex materials including silver nanoparticles [51,52] and gold nanoparticles [53], for their effects on cardiogenesis and neural development. 


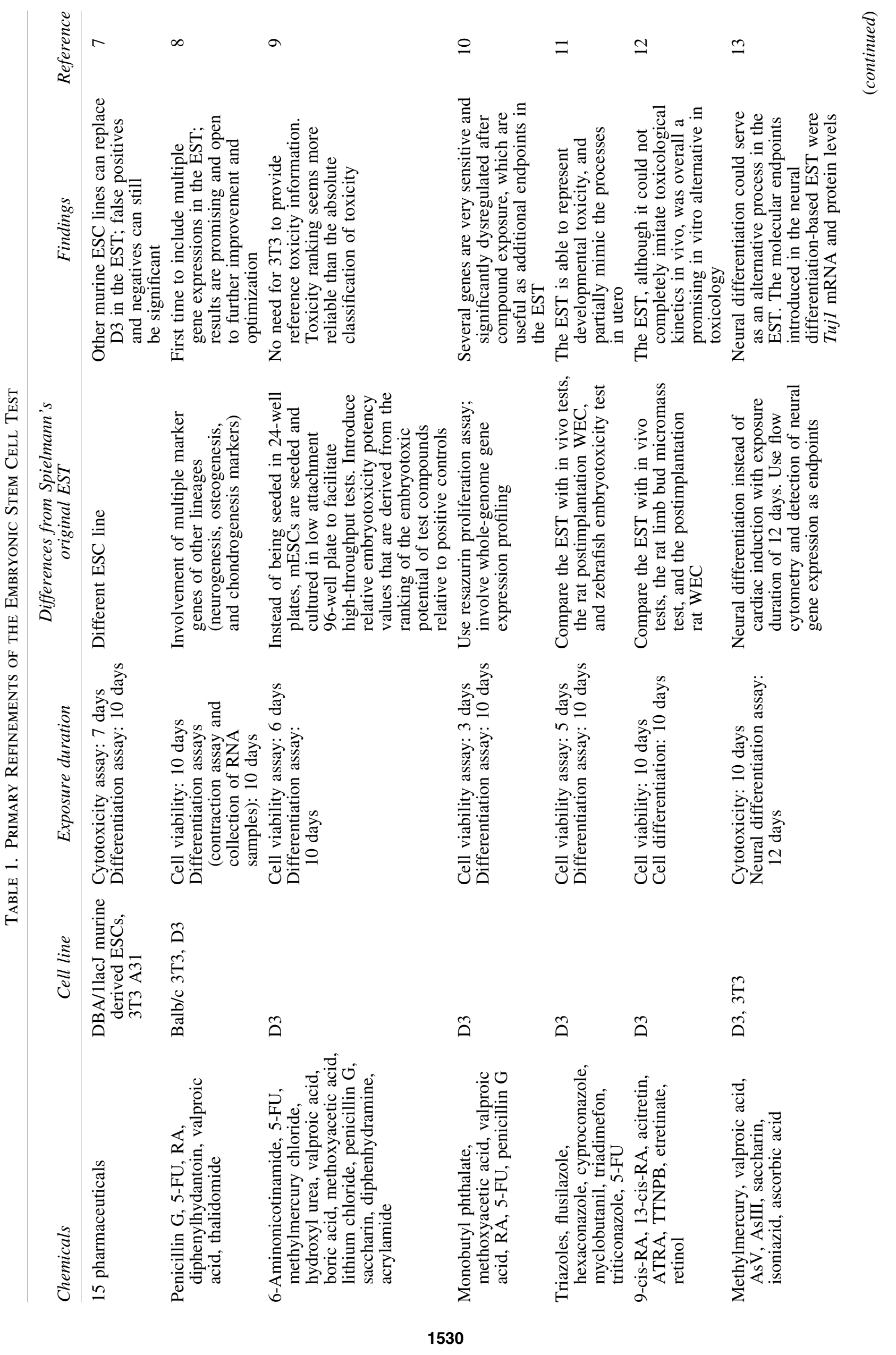




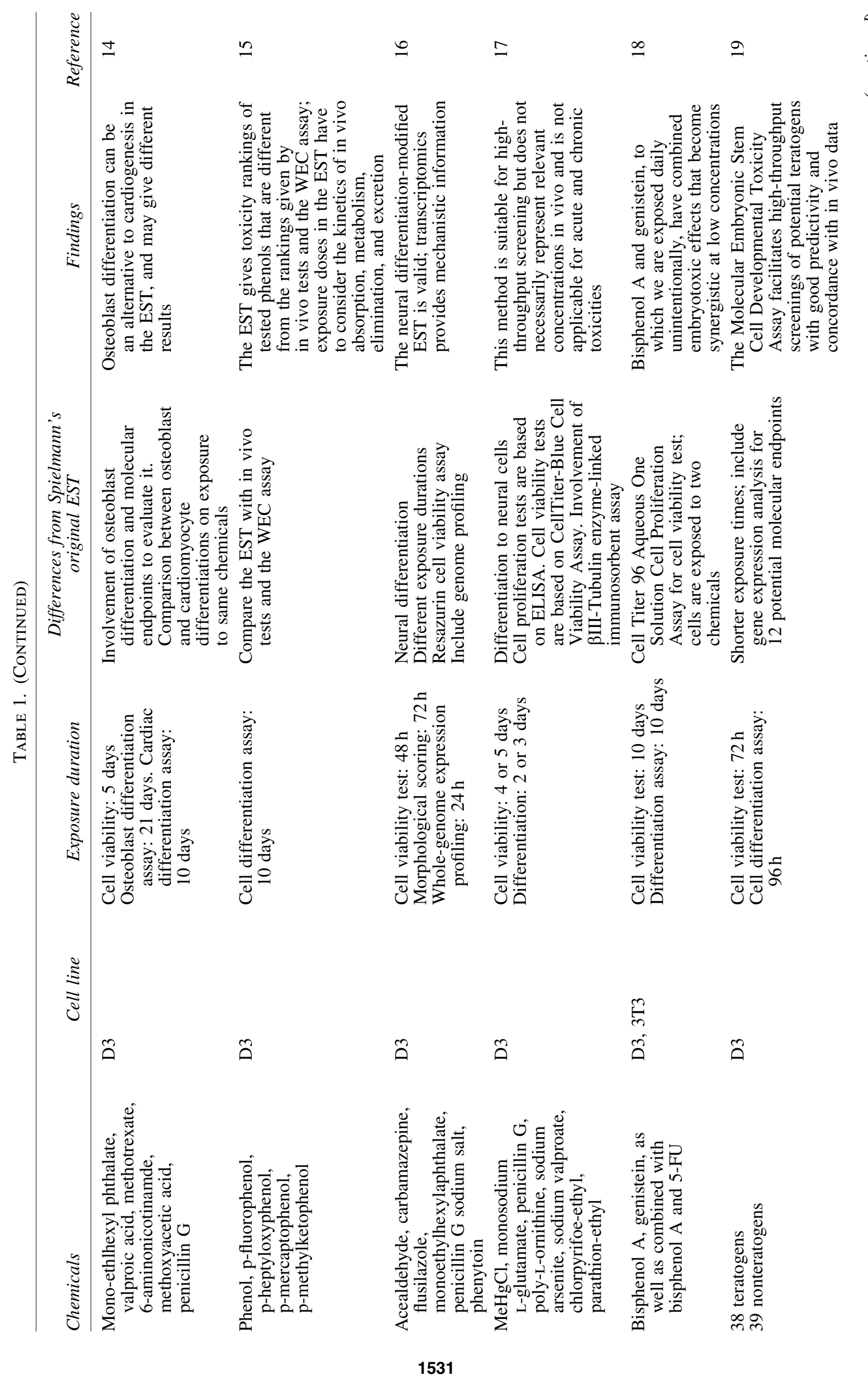




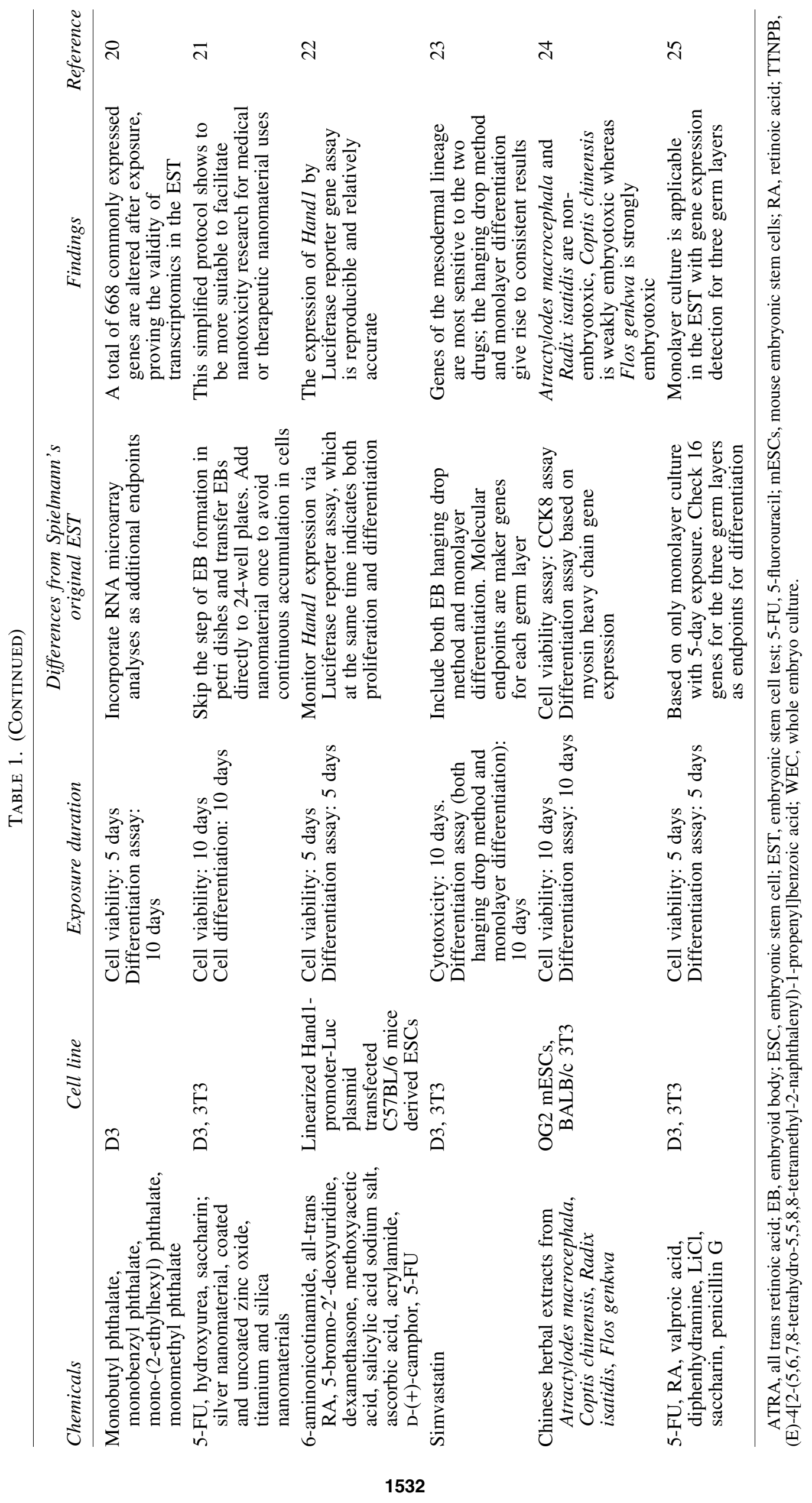


In summary, stem cell toxicology offers great potential and is open to improvements and refinements in parallel with the development of stem cell biology. It would allow for toxicity tests to be designed for many different kinds of cells, with the ultimate goal of obtaining trustable toxic information relative to human health.

\section{Advantages of Stem Cell-Based Toxicity Tests}

The unique properties of stem cells qualify them as one of the best materials for in vitro tests. Unlike primary cells, stem cells, such as ESCs and iPSCs, are able to proliferate extensively in vitro under defined conditions. Theoretically, ESCs and iPSCs can be passaged for indefinite generations without transformation, as established cell lines. Conversely, cancer or immortalized cell lines, although they can be also maintained in vitro indefinitely, are prone to queries as to whether or not they represent healthy or normal cells and are sensitive enough in toxicity assays. Stem cell-based toxicity tests avoid these issues and, consequently, stand out as promising alternatives to animal tests owing to their recapitulating of many key in vivo features.

Stem cells also hold the capacity to differentiate into other cell types. In other words, with proper differentiation conditions, it is possible to generate cells of all the different tissues of the body, including germ cells, in particular when starting from ESCs. These cells can then be used in toxicity studies without ex vivo derivation or ethical concerns. For example, hESCs are able to differentiate into cardiomyocytes, allowing for toxicity assays either during the process of cardiac differentiation or with the terminally differentiated cells [54], therefore permitting developmental and functional toxicity tests, respectively. Thus, stem cells offer the distinct possibility to study cellular, developmental, functional, and reproductive toxicities with various types of stem cells and stem cell-derived offspring, particularly when primary cell types are impossible to be derived directly.

Consistency between stem cell toxicity tests and live animal assays is necessary before concluding that by using stem cells in toxicity assays we can get rid of animal experiments altogether [55]. Summarized in Table 1 are the consistency assessments between EST-based stem cell toxicity tests and in vivo or other in vitro tests, such as the WEC (whole embryo culture) $[11,12,15]$. They revealed a general consistency between in vivo and in vitro results, advocating for the use of stem cell toxicity tests that would also allow for tests with multiple chemicals, doses, and durations at one time, with considerably less consumption of time, money, and labor.

Therefore, the advantages of stem cells mentioned earlier would help face the tremendous challenge of the numerous environmental pollutants, drugs, and industrial chemicals with vague toxicology information $[11,39]$, by employing reliable and high-throughput experimental systems that will eventually contribute to the rise of stem cell toxicology [56].

\section{Major Achievements and Future Prospects of Human Stem Cell Toxicology}

In this section, we focus only on the growing number of research studies recently reported for hESCs and hiPSCs related teratogen and drug screenings, with an emphasis on their potentiality for more comprehensive toxicity assays.

\section{hESC systems as powerful tools for developmental toxicity research}

hESCs are pluripotent, as they have the capacity to differentiate into cells of all three germ layers, as well as germ cells. Thus, toxicity assays with hESCs can provide toxicity information at very early stages after fertilization, since differentiating ESCs mimic the dynamic process of embryonic development. Besides, hESC-derived cells can also serve as a useful alternative to study toxicity effects on a variety of somatic cells.

Cytotoxicity assays on hESCs involve the use of the chemical(s) of interest, to study not only cell death but also whether pluripotency of hESCs would be affected by the chemicals. For example, the embryotoxic compound 5-FU downregulated the expression of Oct4 and Nanog in hESCs, as well as significantly dysregulated HDAC9 (involved in neuronal, skeletal muscle and adipocyte differentiation), DLKI (involved in embryogenesis and differentiation of MSCs to chondrocytes), and NFE2 L3 (involved in differentiation, inflammation, and carcinogenesis) [57], indicating that early exposure to 5-FU may result in multiple malformations. A similar study focused on how teratogens affected the hESC pluripotent state by observing changes in gene networks, and it proposed the explanation that adverse effects occurring during embryonic development might be originated from exposure during very early stages, even before ESCs in the blastocyst start differentiating [58]. Therefore, such a study helps understand how chemicals can influence the process of lineage fate decision in pluripotent cells.

Developmental toxicity tests with the hESC system benefit from the process of embryoid body (EB) formation, which recapitulates the key features of gastrulation [59]. Therefore, toxicity tests during EB formation yield information about which germ layer(s) will be affected and, therefore, which lineage differentiation will be impaired. For example, several natural and synthetic estrogens that readily cross the placenta, such as estradiol, estriol, and bisphenol A, negatively affected endodermal, mesodermal, and ectodermal differentiation during EB formation [49]. Moreover, a common component in toothpaste, fluoride, which had been shown to affect murine and human early embryogenesis, suppressed hESC proliferation and induced apoptosis, but also stimulated the generation of ectoderm and mesoderm at the expenses of endoderm, when administered at high doses [60]. Studies like these have drawn attention to the lack of toxicity information for emerging chemicals that have been widely used.

Toxicity assays for a variety of pharmaceuticals, materials, and environmental pollutants with hESC-derived somatic cells have been performed and validated, implying a great potentiality for these systems in functional toxicology. Cardiomyocytes are one of the earliest cell types being successfully derived from hESCs and have been already used in toxicity tests, for a few common drugs [54,61-63], and in a highthroughput screening for teratogens $[8,44]$. For instance, the chemotherapeutic agent doxorubicin caused acute cytotoxicity in hESC-derived cardiomyocytes, due to membrane damage $[61,62]$. Further, trichloroethylene, a ubiquitously detected industrial chemical, disrupted the transition from cardiac progenitor cells to cardiomyocytes [48]. Neural differentiation of hESCs, as another well-established in vitro process, has been introduced in stem cell toxicology $[64,65]$. Several studies 
showed that a variety of chemicals or materials might impair the development of different types of neural cells [51,53,66,67], and they also deciphered the underlying mechanisms. For example, gold nanoparticles were toxic to neural hESC derivatives, due to the alteration of DNA methylation and hydroxymethylation levels during neural differentiation [53]. In addition, an immediate and significant increase in oxidative stress caused by silver nanoparticle on hESC-derived neural progenitor cells was due to dysregulation at both transcriptional and post-transcriptional levels [52].

There are also studies on more complex neural cell populations, such as neural rosette $[68,69]$ and artificial neural constructs $[50,70]$. For example, highly consistent responses toward RA between in vitro neural rosette and in vivo systems confirmed the potentiality of neural rosette generation for developmental neurotoxicity tests [69]. One promising study focused on the generation of neural constructs, comprising different kinds of cells, in 3D structures mimicking the developing brain. That study obtained highly accurate toxicity results with known neural toxicants and controls [70], and together with another toxicity study based on 3D neural spheres [50], demonstrated the potential of 3D cell constructs or even organoids in toxicology research.

With the establishment of additional hESC-based differentiation protocols, other hESC-based models in toxicology have been validated, and several different kinds of toxicities from a variety of chemicals, materials, and environmental pollutants have been measured. For example, hESC-derived germ cell-like cells have been utilized in reproductive toxicity tests that facilitated and accelerated the screening of the remarkable number of potential endocrine disruptors to which we are continuously exposed [71]. A report on the perturbation of low-dose bisphenol A on the direct differentiation of hESCs into prostate organoids suggested that prenatal exposure could perturb the morphogenesis of the prostate [72].

Besides, systems biology methodologies, such as transcriptomics, proteomics, and metabolomics, have been also incorporated into stem cell toxicology research. For example, one group exposed hESCs to several teratogenic drugs and detected small molecules whose levels were significantly altered in response to those drugs, proving the convenience of metabolomics in toxicity assays [73]. A follow-up toxicity study based on metabolomics achieved an $83 \%$ predictive accuracy [74]. Another investigation using ornithine and cysteine, as indicators of developmental toxicity, identified novel potential teratogens with $77 \%$ accuracy [75], providing evidence for metabolomics effectiveness as an alternative method in toxicology. Optimally, integrating metabolomics, transcriptomics, and proteomics assays in stem cell toxicology would guarantee a more comprehensive analysis of the toxicity mechanisms.

In conclusion, from a toxicological point of view, hESCs have great potential. Novel and versatile toxicity screening platforms based on hESCs are advocated to advance the field of in vitro toxicology.

\section{hiPSCs as promising tools for personalized toxicology analyses}

iPSCs have drawn attention and raised expectations in regenerative medicines, since their discovery. They are equivalent to ESCs in potency, although they are not derived from embryos. In fact, they are generated by reprogramming somatic cells, generally obtained from an adult individual, into the pluripotent state. Thus, this method could provide a large quantity of patient-specific pluripotent cells with no immune response issues for potential cell base transplantations and other clinical applications. Moreover, hiPSCs come with almost no ethical concerns compared with the derivation and use of hESCs. Besides regenerative medicine, iPSCs can potentially be employed for drug development and toxicology studies, as previously reviewed [76-79]. A study comparing the neurotoxicity effects of KG-501, an inhibitor of the CREB pathway, on hESC- and hiPSC-derived neurons and glia, verified the potentialities of hiPSCs in neural developmental toxicity assays [80]. Cardiomyocyte and hepatogenic differentiation from hiPSC has been also employed for drug screenings. Table 2 summarizes the findings in several drug screenings based on iPSC-derived cardiomyocytes and hepatocytes, proving the robustness of these models.

Reprogramming enables generation of iPSCs from patients as well as healthy people. In this respect, toxicology research can target different populations. For example, iPSC-derived cardiomyocytes from patients whose genetic backgrounds made them more prone to cardiac diseases resulted in more sensitivity to perturbations by cardio-toxic drugs, whereas cardiomyocytes from healthy people were more tolerant [85]. One investigation compared doxorubicin-induced toxicity in iPSC-derived cardiomyocytes from breast cancer patients who either suffered from doxorubicin-induced cardiotoxicity or did not. Results showed that cardiomyocytes derived from patients who experienced doxorubicin-induced cardiotoxicity were more sensitive to doxorubicin [89].

Further, iPSC-derived neural cells provide great research material, especially for patient-specific neurotoxicity information. Efforts on modeling neurotoxicity with iPSCderived neural cell types are emphasized in one study about chemotherapy-induced toxicity [90], as well as in two others on embracing hiPSC neural differentiation in highthroughput screenings $[91,92]$. Those examples also clearly demonstrate that hiPSC-based assays are open to improvement and adaptation to personalized toxicology analysis for diagnosis and therapies.

Taking everything together, hiPSC applications in medical research and drug screenings support the idea of employing them as well as iPSC-derived cells in stem cell toxicology. In fact, those methods offer the possibility of a more personalized toxicology in that they allow to investigate whether patients or specific groups of healthy people with different genetic backgrounds respond differently to toxicants. However, there have not yet been a lot of persuasive reports on toxicity assays of environmental chemicals based on hiPSCs [93].

\section{Conclusive Remarks}

Currently, toxicology still heavily relies on live animal tests, which are prone to errors due to interspecies inconsistencies [94] when we applied them to predict human health risks. Unlike drug screenings, which always include clinical trials with human volunteers, toxicology tests cannot rely on human subjects directly. In addition, we are continuously exposed to a variety of different chemicals, 
Table 2. Drug Screening and Toxicity Assays Based on Human-Induced Pluripotent Stem Cell-Derived CARDiomyocytes or HePATOCYTES

\begin{tabular}{|c|c|c|c|}
\hline $\begin{array}{l}\text { Differentiation } \\
\text { lineage }\end{array}$ & Drug & Findings & Reference \\
\hline Hepatocyte & $\begin{array}{l}\text { Amiodarone } \\
\text { Alatoxin B1 } \\
\text { Troglitazone } \\
\text { Ximelagatran }\end{array}$ & $\begin{array}{l}\text { Amiodarone, Alatoxin B1 and Troglitazone cause dose-dependent } \\
\text { toxic effects on hiPSC-derived hepatocytes after } 14 \text { days of } \\
\text { exposure. There is specific induction of phospholipidosis } \\
\text { and steatosis after exposure. hiPSC-derived hepatocytes show } \\
\text { time-dependent toxicity effects from exposure to the drugs, } \\
\text { suggesting that the model is applicable in long-term toxicity } \\
\text { test and that certain drugs may have accumulative toxic } \\
\text { effects on the liver }\end{array}$ & 62 \\
\hline Hepatocyte & 24 drugs & $\begin{array}{l}\text { 3D spheroid culture of hepatocytes not only produces high } \\
\text { efficiencies but also allows cells to grow with better oxygen } \\
\text { conditions, which gives rise to more functional hepatocytes } \\
\text { with enhanced performance in drug screenings }\end{array}$ & 81 \\
\hline Hepatocyte & $\begin{array}{l}238 \text { compounds from } \\
\text { the Screen-Well }{ }^{\mathrm{TM}} \\
\text { Hepatotoxicity Library } \\
\text { (Enzo Life Sciences) }\end{array}$ & $\begin{array}{l}\text { High-content automated screening assays based on hiPSC-derived } \\
\text { hepatocytes provide information on cell viability, nuclear shape } \\
\text { and intensity, cytoskeleton integrity, mitochondrial potential, } \\
\text { autophagy, and lipid accumulation by different staining methods }\end{array}$ & 82 \\
\hline Hepatocyte & $\begin{array}{l}\text { Staurosporine } \\
\text { Acetaminophen }\end{array}$ & $\begin{array}{l}\text { hiPSC-derived hepatocytes are highly similar to human primary } \\
\text { hepatocytes in regulating and executing apoptosis after drug } \\
\text { exposure, compared with two other human liver cell lines, } \\
\text { suggesting that hiPSC-derived hepatocytes are a good } \\
\text { alternative to primary hepatocytes }\end{array}$ & 83 \\
\hline Cardiomyocyte & 24 drugs & $\begin{array}{l}\text { hiPSC-derived cardiomyocytes show impedance changes } \\
\text { after drug exposure. }\end{array}$ & 84 \\
\hline Cardiomyocyte & $\begin{array}{l}\text { Cisapride } \\
\text { Nicorandil } \\
\text { Alfuzosin } \\
\text { Verapamil }\end{array}$ & $\begin{array}{l}\text { Although iPSC-derived cardiomyocytes are not as mature } \\
\text { as cardiomyocytes derived from the human body, based } \\
\text { on their gene expression, iPSC-derived cardiomyocytes } \\
\text { can be utilized in drug screenings, especially suitable } \\
\text { for toxicity tests for high-risk populations }\end{array}$ & 85 \\
\hline Cardiomyocyte & $\begin{array}{l}131 \text { drugs consisting } \\
\text { of both cardiotoxic } \\
\text { and cardio-safe ones }\end{array}$ & $\begin{array}{l}\text { 384-well plate-based toxicity assays with good accuracy } \\
\text { in classification of cardiotoxicity of drugs }\end{array}$ & 86 \\
\hline Cardiomyocyte & Ponatinib & $\begin{array}{l}\text { Ponatinib induces cell death, troponin secretion, and reactive } \\
\text { oxygen species and lipid formation, inhibits ABL activation } \\
\text { and survival pathways, and disrupts actin cytoskeleton } \\
\text { structures and beating of hiPSC-derived cardiomyocytes, } \\
\text { at medical significant doses }\end{array}$ & 87 \\
\hline Cardiomyocyte & 23 drugs & $\begin{array}{l}\text { Toxicity endpoints for hiPSC-derived cardiomyocytes cell } \\
\text { viability and function provide robust evaluation of drug toxicity }\end{array}$ & 88 \\
\hline Cardiomyocyte & Doxorubicin & $\begin{array}{l}\text { iPSC-derived cardiomyocytes from patients experiencing } \\
\text { doxorubicin-induced cardiotoxicity are more sensitive than } \\
\text { the ones from patients who do not experience cardiotoxicity }\end{array}$ & 89 \\
\hline
\end{tabular}

hiPSC, human-induced pluripotent stem cell.

including emerging environmental pollutants, which present potentially high risk for our health. Thus, reliable toxicity models based on the human physiology are needed to assess the adverse effects of all these chemicals on humans [95].

More than 20 years of exploration of ESC-based in vitro toxicity assays confirmed the importance of stem cells in toxicology research. Human PSCs enable toxicologists to study developmental toxicity, as well as functional toxicities on mature terminally differentiated cell types that are difficult to be derived directly from humans. The development of human stem cell toxicology benefited from all the efforts in the design and improvement of the mouse EST, which was the first stem cell-based developmental toxicity test to eliminate the use of pregnant animals. Nowadays, hPSC-derived cardiomyocytes, neural cells, and hepatocytes are major lineages being employed. However, more stem cell-derived lineages, such as intestinal, gastric, and pulmonary cells, should be implemented in developmental and functional toxicity tests. In particular, differentiation of hESCs/iPSCs into primordial germ cells and gametes would broaden the scope of the in vitro reproductive toxicity investigations. In addition, advances in the synthesis of biomaterials, and conditions for $3 \mathrm{D}$ culture and differentiation of hESCs, have allowed the generation of more complex cell constructs, which provide a dynamic cell system resembling the in vivo situation more comprehensively than 2D systems. This would also make toxicology more predictive. The breakthrough of the generation of hiPSCs has also permitted drug screenings and toxicity 
assays with cells derived from patients, building the foundations for a more personalized toxicology.

In conclusion, stem cell toxicology, although still developing, has already been proved to be a very comprehensive toxicity system, which allows for the assessment of embryonic, developmental, organ, reproductive, and functional toxicities. When fully evolved, it will definitely represent the gold standard for in vitro toxicology.

\section{Acknowledgments}

The authors were funded by grants from the Chinese Academy of Sciences Strategic Priority Research Program (XDB14040301), the National Natural Science Foundation of China (21577166), the Chinese Academy of Sciences Hundred Talent Program (29[2015]30), and the Key Research Program of Frontier Sciences, CAS (QYZDJ-SSW-DQC017).

\section{Author Disclosure Statement}

No competing financial interests exist.

\section{References}

1. Russel WMS and RL Burch, ed. (1959). The Principles of Humane Experimental Technique. Methuen \& Co., London. Special edition published by Universities Federation for Animal Welfare (UFAW), 1992.

2. Schwetz BA, RE Morrissey, F Welsch and RA Kavlock. (1991). In vitro teratology. Environ Health Perspect 94: 265-268.

3. Evans MJ and MH Kaufman. (1981). Establishment in culture of pluripotential cells from mouse embryos. Nature 292:154-156.

4. Takahashi $\mathrm{K}$ and S Yamanaka. (2006). Induction of pluripotent stem cells from mouse embryonic and adult fibroblast cultures by defined factors. Cell 126:663676.

5. Laschinski G, R Vogel and H Spielmann. (1991). Cytotoxicity test using blastocyst-derived euploid embryonal stem cells - a new approach to in vitro teratogenesis screening. Reprod Toxicol 5:57-64.

6. Spielmann H, I Pohl, B Döring, M Liebsch and F Moldenhauer. (1997). The embryonic stem cell test, an in vitro embryotoxicity test using two permanent mouse cell lines: 3 T3 fibroblasts and embryonic stem cells. In Vitro Toxicol 10:119-127.

7. Paquette JA, SW Kumpf, RD Streck, JJ Thomson, RE Chapin and DB Stedman. (2008). Assessment of the embryonic stem cell test and application and use in the pharmaceutical industry. Birth Defects Res B Dev Reprod Toxicol 83:104-111.

8. zur Nieden NI, G Lempka and HJ Ahr. (2004). Molecular multiple endpoint embryonic stem cell test-a possible approach to test for the teratogenic potential of compounds. Toxicol Appl Pharmacol 194:257-269.

9. Peters AK, M Steemans, E Hansen, N Mesens, GR Verheyen and P Vanparys. (2008). Evaluation of the embryotoxic potency of compounds in a newly revised high throughput embryonic stem cell test. Toxicol Sci 105:342350.

10. van Dartel DA, JL Pennings, LJ de la Fonteyne, MH van Herwijnen, JH van Delft, FJ van Schooten and AH Piersma. (2010). Monitoring developmental toxicity in the embry- onic stem cell test using differential gene expression of differentiation-related genes. Toxicol Sci 116:130-139.

11. de Jong E, M Barenys, SA Hermsen, A Verhoef, BC Ossendorp, JG Bessems and AH Piersma. (2011). Comparison of the mouse embryonic stem cell test, the rat whole embryo culture and the zebrafish embryotoxicity test as alternative methods for developmental toxicity testing for six 1,2,4-triazoles. Toxicol Appl Pharmacol 253:103-111.

12. Louisse J, S Gönen, IMCM Rietjens and M Verwei. (2011). Relative developmental toxicity potencies of retinoids in the embryonic stem cell test compared with their relative potencies in in vivo and two other in vitro assays for developmental toxicity. Toxicol Lett 203:1-8.

13. Baek DH, TG Kim, HK Lim, JW Kang, SK Seong, SE Choi, SY Lim, SH Park, BH Nam, et al. (2011). Embryotoxicity assessment of developmental neurotoxicants using a neuronal endpoint in the embryonic stem cell test. J Appl Toxicol 32:617-626.

14. de Jong E, L van Beek and AH Piersma. (2012). Osteoblast differentiation of murine embryonic stem cells as a model to study the embryotoxic effect of compounds. Toxicol In Vitro 26:970-978.

15. Strikwold M, RA Woutersen, B Spenkelink, A Punt and IMC Rietjens. (2012). Relative embryotoxic potency of psubstituted phenols in the embryonic stem cell test (EST) and comparison to their toxic potency in vivo and in the whole embryo culture (WEC) assay. Toxicol Lett 213:235-242.

16. Theunissen PT, JF Robinson, JL Pennings, MH can Herwijnen, JC Kleinjans and AH Piersma. (2012). Compoundspecific effects of diverse neurodevelopmental toxicants on global gene expression in the neural embryonic stem cell test (ESTn). Toxicol Appl Pharmacol 262:330-340.

17. Hayess K, C Riebeling, R Pirow, M Steinfath, D Sittner, B Slawik, A Luch and AE Seiler. (2013). The DNT-EST: a predictive embryonic stem cell-based assay for developmental neurotoxicity testing in vitro. Toxicology 314: $135-147$

18. Kong D, L Xing, R Liu, J Jiang, W Wang, L Shang, X Wei and W Hao. (2013). Individual and combined developmental toxicity assessment of bisphenol A and genistein using the embryonic stem cell test in vitro. Food Chem Toxicol 60:497-505.

19. Panzica-Kelly JM, KC Brannen, Y Ma, CX Zhang, OP Flint, LD Lehman-McKeeman and KA Augustine-Rauch. (2013). Establishment of a molecular embryonic stem cell developmental toxicity assay. Toxicol Sci 131:447-457.

20. Schulpen SHW, JF Robinson, JLA Pennings, DAM van Dartel and AH Piersma. (2013). Dose response analysis of monophthalates in the murine embryonic stem cell test assessed by cardiomyocyte differentiation and gene expression. Reprod Toxicol 35:81-88.

21. Corradi S, E Dakou, A Yadav, LC Thomassen, M KirschVolders and L Leyns. (2015). Morphological observation of embryoid bodies completes the in vitro evaluation of nanomaterial embryotoxicity in the embryonic stem cell test (EST). Toxicol In Vitro 29:1587-1596.

22. le Coz F, N Suzuki, H Nagahori, T Omori and K Saito. (2015). Hand1-Luc embryonic stem cell test (Hand1-Luc EST): a novel rapid and highly reproducible in vitro test for embryotoxicity by measuring cytotoxicity and differentiation toxicity using engineered mouse ES cells. J Toxicol Sci 40:251-261.

23. Jyoti S and S Tandon. (2015). Genetic basis for developmental toxicity due to statin intake using embryonic stem cell differentiation model. Hum Exp Toxicol 34:965-984. 
24. Li LY, FF Cao, ZJ Su, QH Zhang, XY Dai, X Xiao, YD Huang, Q Zheng and $\mathrm{H} \mathrm{Xu.} \mathrm{(2015).} \mathrm{Assessment} \mathrm{of} \mathrm{the}$ embryotoxicity for four Chinese herbal extracts using embryonic stem cell test. Mol Med Rep 12:2348-2354.

25. Romero AC, E del Rio, E Vilanova and MA Sogorb. (2015). RNA transcripts for the quantification of differentiation allow marked improvements in the performance of embryonic stem cell test (EST). Toxicol Lett 238:60-69.

26. Seiler AEM and H Spielmann. (2011). The validated embryonic stem cell test to predict embryotoxicity in vitro. Nat Protoc 6:961-978.

27. Seiler A, A Visan, R Buesen, E Genschow and H Spielmann. (2004). Improvement of an in vitro stem cell assay for developmental toxicity: the use of molecular endpoints in the embryonic stem cell test. Reprod Toxicol 18:231-240.

28. Buesen R, E Genschow, B Slawik, A Visan, H Spielmann, A Luch and A Seiler. (2009). Embryonic stem cell test remastered: comparison between the validated EST and the new molecular FACS-EST for assessing developmental toxicity in vitro. Toxicol Sci 108:389-400.

29. Pennings JLA, DAM van Dartel, JF Robinson, TE Pronk and AH Piersma. (2012). Gene set assembly for quantitative prediction of developmental toxicity in the embryonic stem cell test. Toxicology 284:63-71.

30. van Dartel DA, JL Pennings, LJ de la Fonteyne, KJ Brauers, S Claessen, JH van Delft, JC Kleinjans and AH Piersma. (2011). Concentration-dependent gene expression responses to flusilazole in embryonic stem cell differentiation cultures. Toxicol Appl Pharmacol 251:110-118.

31. Chen X, DK Hansen, G Merry, C DeJarnette, G Nolen, D Sloper, JE Fisher, W Harrouk, MS Tassinari and AL Inselman. (2015). Developing osteoblasts as an endpoint for the mouse embryonic stem cell test. Reprod Toxicol 53: 131-140.

32. van Dartel DA, SH Schulpen, PT Theunissen, A Bunschoten, AH Piersma and J Keijer. (2014). Dynamic changes in energy metabolism upon embryonic stem cell differentiation support developmental toxicant identification. Toxicology 324:76-87.

33. Festag M, B Viertel, P Steinberg and C Sehner. (2007). An in vitro embryotoxicity assay based on the disturbance of the differentiation of murine embryonic stem cells into endothelial cells. II. Testing of compounds. Toxicol In Vitro 21:1631-1640.

34. Barrier M, S Jeffay, HP Nichols, KJ Chandler, MR Hoopes, K Slentz-Kesler and ES $3^{\text {rd }}$ Hunter. (2011). Mouse embryonic stem cell adherent cell differentiation and cytotoxicity (ACDC) assay. Reprod Toxicol 31:383-391.

35. Chandler KJ, M Barrier, S Jeffay, HP Nichols, NC Kleinstreuer, AV Singh, DM Reif, NS Sipes, RS Judson, et al. (2011). Evaluation of 309 environmental chemicals using a mouse embryonic stem cell adherent cell differentiation and cytotoxicity assay. PLoS One 6:e18540.

36. Thomson JA, J Itskovitz-Eldor, SS Shapiro, MA Waknitz, JJ Swiergiel, VS Marshall and JM Jones. (1998). Embryonic stem cell lines derived from human blastocysts. Science 282:1145-1147.

37. Ginis I, Y Luo, T Miura, S Thies, R Brandenberger, S Gerecht-Nir, M Amit, A Hoke, MK Carpenter, J ItskovitzEldor and MS Rao. (2004). Differences between human and mouse embryonic stem cells. Dev Biol 269:360-380.

38. Hanna J, AW Cheng, K Saha, J Kim, CJ Lengner, F Soldner, JP Cassady, J Muffat, BW Carey and R Jaenisch. (2010). Human embryonic stem cells with biological and epigenetic characteristics similar to those of mouse ESCs. Proc Natl Acad Sci (USA) 107:9222-9227.

39. Flora SJS and A Mehta. (2009). Monoisoamyl dimercaptosuccinic acid abrogates arsenic-induced developmental toxicity in human embryonic stem cell-derived embryoid bodies: comparison with in vivo studies. Biochem Pharmacol 78:1340-1349.

40. He X, S Imanishi, H Sone, R Nagano, XY Qin, J Yoshinaga, H Akanuma, J Yamane, W Fujibuchi and S Ohsako. (2012). Effects of methylmercury exposure on neuronal differentiation of mouse and human embryonic stem cells. Toxicol Lett 212:1-10.

41. Lin S, V Tran and P Talbot. (2009). Comparison of toxicity of smoke from traditional and harm-reduction cigarettes using mouse embryonic stem cells as a novel model for preimplantation development. Hum Reprod 24:386-397.

42. Lin S, S Fonteno, J Weng and P Talbot. (2010). Comparison of the toxicity of smoke from conventional and harm reduction cigarettes using human embryonic stem cells. Toxicol Sci 118:202-212.

43. Meganathan K, S Jagtap, V Wagn, J Winkler, JA Gaspar, D Hildebrand, M Trusch, K Lehamann, J Hescheler, H Schlüter and A Sachinidis. (2012). Identification of thalidomidespecific transcriptomics and proteomics signatures during differentiation of human embryonic stem cells. PLos One 7:e44228.

44. Mayshar Y, O Yanuka and N Benvenisty. (2011). Teratogen screening using transcriptome profiling of differentiating human embryonic stem cells. J Cell Mol Med 15: 1393-1401.

45. Nash R, M Krishnamoorthy, A Jenkins and M Csete. (2012). Human embryonic stem cell model of ethanol-mediated developmental toxicity. Exp Neurol 234:127-135.

46. Zeng X, J Chen, X Deng, Y Liu, MS Rao, JL Cadet and WJ Freed. (2006). An in vitro model of human dopaminergic neurons derived from embryonic stem cells: MPP+ toxicity and GDNF neuroprotection. Neuropsychopharmacology 31:2708-2715.

47. Adler S, C Pellizzer, L Hareng, T Hartung and S Bremer. (2008). First steps in establishing a developmental toxicity test method based on human embryonic stem cells. Toxicol In Vitro 22:200-211.

48. Jiang Y, D Wang, G Zhang, J Tong and T Chen. (2015). Disruption of cardiogenesis in human embryonic stem cells exposed to trichloroethylene. Environ Toxicol 31:1372-1380.

49. Kim H, YY Kim, SY Ku, SH Kim, YM Choi and SY Moon. (2013). The effect of estrogen compounds on human embryoid bodies. Reprod Toxicol 20:661-669.

50. Sandström J, E Eggermann, I Charvet, A Roux, N Toni, C Greggio, A Broyer, F Monnet-Tschudi and L Stoppini. (2017). Development and characterization of a human embryonic stem cell-derived 3D neural tissue model for neurotoxicity testing. Toxicol In Vitro 38:124-135.

51. Begum AN, JS Aguilar, L Elias, and Y Hong. (2016). Silver nanoparticles exhibit coating and dose-dependent neurotoxicity in glutamatergic neurons derived from human embryonic stem cells. Neurotoxicology 57:45-53.

52. Oh JH, MY Son, MS Choi, S Kim, AY Choi, HA Lee, KS Kim, J Kim, CW Song and S Yoon. (2016). Integrative analysis of genes and miRNA alterations in human embryonic stem cell-derived neural cells after exposure to silver nanoparticles. Toxicol Appl Pharmacol 299:8-23.

53. Senut M, Y Zhang, F Liu, A Sen, DM Ruden and G Mao. (2016). Size-dependent toxicity of gold nanoparticles on 
human embryonic stem cells and their neural derivatives. Small 12:631-646.

54. Braam SR, L Tertoolen, A van de Stolpe, T Meyer, R Passier and CL Mummery. (2010). Prediction of drug-induced cardiotoxicity using human embryonic stem cell-derived cardiomyocytes. Stem Cell Res 4:107-116.

55. Trosko JE and C Chang. (2010). Factors to consider in the use of stem cells for pharmaceutic drug development and for chemical safety assessment. Toxicology 270:18-34.

56. Faiola F, N Yin, X Yao and G Jiang. (2015). The rise of stem cell toxicology. Environ Sci Technol 49:5847-5848.

57. Jung EM, YU Choi, HS Kang, H Yang, EJ Hong, BS An, JY Yang, KH Choi and EB Jeung. (2015). Evaluation of developmental toxicity using undifferentiated human embryonic stem cells. J Appl Toxicol 35:205-218.

58. Yamane J, S Aburatani, S Imanishi, H Akanuma, R Nagano, T Kato, H Sone, S Ohsako and W Fujibuchi. (2016). Prediction of developmental chemical toxicity based on gene networks of human embryonic stem cells. Nucleic Acids Res 44:5515-5528.

59. Mehta A, VBR Konala, A Khanna and AS Majumdar. (2008). Assessment of drug induced developmental toxicity using human embryonic stem cells. Cell Biol Int 32:1412-1424.

60. Fu X, FN Xie, P Dong, QC Li, GY Yu and R Xiao. (2016). High-dose fluoride impairs the properties of human embryonic stem cells via JNK signaling. PLoS One 11:e0148819.

61. Andersson H, D Steel, J Asp, K Dahlenborg, M Jonsson, A Jeppsson, A Lindahl, B Kagedal, P Sartipy and C Mandenius. (2010). Assaying cardiac biomarkers for toxicity testing using biosensing and cardiomyocytes derived from human embryonic stem cells. J Biotechnol 150:175-181.

62. Holmgren G, AK Sjögren, I Barragan, A Sabirsh, P Sartipy, J Synnergren, $\mathrm{P}$ Björquist, $\mathrm{M}$ Ingelman-Sundberg, TB Andersson and J Edsbagge. (2014). Long-term toxicity testing using human pluripotent stem cell-derived hepatocytes. Drug Metab Dispos 42:1401-1406.

63. Zhao Q, X Wang, S Wang, Z Song, J Wang and J Ma. (2017). Cardiotoxicity evaluation using human embryonic stem cells and induced pluripotent stem cell-derived cardiomyocytes. Stem Cell Res Ther 8:54.

64. Schulpen SHW, E de Jong, LJJ de la Fonteyne, A de Klerk and AH Piersma. (2015). Distinct gene expression responses of two anticonvulsant drugs in a novel human embryonic stem cell based neural differentiation assay protocol. Toxicol In Vitro 29:449-457.

65. Schulpen SHW, JLA Pennings and AH Piersma. (2015). Gene expression regulation and pathway analysis after valproic acid and carbamazepine exposure in a human embryonic stem cell-based neurodevelopmental toxicity assay. Toxicol Sci 146:311-320.

66. Ehashi T, N Suzuki, S Ando, K Sumida and K Saito. (2014). Effects of valproic acid on gene expression during human embryonic stem cell differentiation into neurons. J Toxicol Sci 39:383-390.

67. Stummann TC, L Hareng and S Bremer. (2009). Hazard assessment of methylmercury toxicity to neuronal induction in embryogenesis using human embryonic stem cells. Toxicology 257:117-126.

68. Colleoni S, C Galli, SG Giannelli, MT Armentero, F Blandini, V Broccoli and G Lazzari. (2010). Long-term culture and differentiation of CNS precursors derived from anterior human neural rosettes following exposure to ventralizing factors. Exp Cell Res 316:1148-1158.
69. Colleoni S, C Galli, JA Gaspar, K Meganathan, S Jagtap, J Hescheler, A Sachinidis and G Lazzari. (2011). Development of a neural teratogenicity test based on human embryonic stem cells: response to retinoic acid exposure. Toxicol Sci 124:370-377.

70. Schwartz MP, Z Hou, NE Propson and J Thomson. (2015). Human pluripotent stem cell-derived neural constructs for predicting neural toxicity. Proc Natl Acad Sci U S A 112:12516-12521.

71. West FD, WM Henderson, P Yu, JY Yang, SL Stice and MA Smith. (2012). Metabolomic response of human embryonic stem cell-derived germ-like cells after exposure to steroid hormones. Toxicol Sci 129:9-20.

72. Calderon-Gierszal EL and GS Prins. (2015). Directed differentiation of human embryonic stem cells into prostate organoids in vitro and its perturbation by low-dose bisphenol A exposure. PLoS One 10:e0133238.

73. West PR, Weir AM, Smith AM, Donley ELR and GG Cezar. (2010). Predicting human developmental toxicity of pharmaceuticals using human embryonic stem cells and metabolomics. Toxicol Appl Pharmacol 247:18-27.

74. Kleinstreuer NC, AM Smith and PR West. (2011). Identifying developmental toxicity pathways for a subset of ToxCast chemicals using human embryonic stem cells and metabolomics. Toxicol Appl Pharmacol 257:111-121.

75. Palmer JA, AM Smith, LA Egnash, KR Conard, PR West, RE Burrier, EL Donley and FR Kirchner. (2013). Establishment of assessment of a new human embryonic stem cellbased biomarker assay for developmental toxicity screening. Birth Defects Res B Dev Reprod Toxicol 98:343-363.

76. Baxter MA, C Rowe, J Alder, S Harrison, KP Hanley, BK Park, NR Kitteringham, CE Goldring and NA Hanley. (2010). Generating hepatic cell lineages from pluripotent stem cells for drug toxicity screening. Stem Cell Res 5:4-22.

77. Sartipy P and P Björquist. (2011). Concise review: Human pluripotent stem cell-based models for cardiac and hepatic toxicity assessment. Stem Cells 29:744-748.

78. Hou Z, J Zhang, MP Schwartz, R Stewart, CD Page, WL Murphy and JA Thomson. (2013). A human pluripotent stem cell platform for assessing developmental neural toxicity screening. Stem Cell Res Ther 4 (Suppl1):S12.

79. Sinnecker D, K Laugwitz and A Moretti. (2014). Induced pluripotent stem cell-derived cardiomyocytes for drug development and toxicity testing. Pharmacol Ther 143: 246-252.

80. Pistollato F, J Louisse, B Scelfo, M Mennecozzi, B Accordi, G Basso, JA Gaspar, D Zagoura, M Barilari, et al. (2014). Development of a pluripotent stem cell derived neuronal model to identify chemically induced pathway perturbations in relation to neurotoxicity: Effects of CREB pathway inhibition. Toxicol Appl Pharmacol 280:378-388.

81. Takayama K, K Kawabata, Y Nagamoto, K Kishimoto, K Tashiro, F Sakurai, M Tachibana, K Kanda, T Hayakawa, MK Furue and H Mizuguchi. (2013). 3D spheroid culture of hESC/hiPSC-derived hepatocyte-like cells for drug toxicity testing. Biomaterials 34:1781-1789.

82. Sirenko O, J Hesley, I Rusyn and EF Cromwell. (2014). Highcontent assays for hepatotoxicity using induced pluripotent stem cell-derived cells. Assay Drug Dev Technol 12:43-54.

83. Sjogren AK, M Liljevald, B Glinghammar, J Sagemark, XQ Li, A Jonebring, I Cotgreave, G Brolén and TB Andersson. (2014). Critical differences in toxicity mechanisms in induced pluripotent stem cell-derived hepatocytes, 
hepatic cell lines and primary hepatocytes. Arch Toxicol 88:1427-1437.

84. Guo L, RM Abrams, JE Babiarz, JD Cohen, S Kameoka, MJ Sanders, E Chiao and KL Colaja. (2011). Estimating the risk of drug-induced proarrhythmia using human induced pluripotent stem cell-derived cardiomyocytes. Toxicol Sci 123:281-289.

85. Liang P, F Lan, AS Lee, T Gong, V Sanchez-Freire, Y Wang, S Diecke, K Sallam, JW Knowles, et al. (2013). Drug screening using a library of human induced pluripotent stem cell-derived cardiomyocytes reveals disease-specific patterns of cardiotoxicity. Circulation 127:1677-1691.

86. Sirenko O, EF Cromwell, C Crittenden, JA Wignall, FA Wright and I Rusyn. (2013). Assessment of beating parameters in human induced pluripotent stem cells enables quantitative in vitro screening for cardiotoxicity. Toxicol Appl Pharmacol 273:500-507.

87. Talbert DR, KR Doherty, PB Trusk, DM Moran, SA Shell and S Bacus. (2015). A multi-parameter in vitro screen in human stem cell-derived cardiomyocytes identifies ponatinibinduced structural and functional cardiac toxicity. Toxicol Sci 143:147-155.

88. Doherty KR, DR Talbert, PB Trusk, DM Moran, SA Shell and S Bacus. (2015). Structural and functional screening in human induced-pluripotent stem cell-derived cardiomyocytes accurately identifies cardiotoxicity of multiple drug types. Toxicol Appl Pharmacol 285:51-60.

89. Burridge PW, YF Li, E Matsa, H Wu, SG Ong, A Sharma, A Holmström, AC Chang, MJ Coronado, et al. (2016). Human induced pluripotent stem cell-derived cardiomyocytes recapitulate the predilection of breast cancer patients to doxorubicin-induced cardiotoxicity. Nat Med 22:547-556.

90. Wheeler HE, C Wing, SM Delaney, MM Komatsu and E Dolan. (2015). Modeling chemotherapeutic neurotoxicity with human induced pluripotent stem cell-derived neuronal cells. PLoS One 10:e0118020.
91. Pei Y, J Peng, M Behl, NS Sipes, KR Shockley, MS Rao, RR Tice and X Zeng. (2016). Comparative neurotoxicity screening in human iPSC-derived neural stem cells, neurons and astrocytes. Brain Res 1638:57-73.

92. Ryan KR, O Sirenko, F Parham, JH Hsieh, EF Cromwell, RR Tice and M Behl. (2016). Neurite outgrowth in human induced pluripotent stem cell-derived neurons as a highthroughput screen for developmental neurotoxicity or neurotoxicity. Neurotoxicology 53:271-281.

93. Yamada S, M Asanagi, N Hirata, H Itagaki, Y Sekino and Y Kanda. (2016). Tributyltin induces mitochondrial fission through Mfn1 degradation in human induced pluripotent stem cells. Toxicol In Vitro 34:257-263.

94. Jennings P. (2014). The future of in vitro toxicology. Toxicol In Vitro 29:1217-1221.

95. La Farré M, S Pérez, L Kantiani and D Barceló. (2008). Fate and toxicity of emerging pollutants, their metabolites and transformation products in the aquatic environment. TrAC Trends Anal Chem 27:991-1007.

Address correspondence to:

Francesco Faiola

State Key Laboratory of Environmental Chemistry and Ecotoxicology

Research Center for Eco-Environmental Sciences Chinese Academy of Sciences Beijing 100085 P.R. China

E-mail: faiola@rcees.ac.cn

Received for publication July 20, 2017 Accepted after revision September 5, 2017 Prepublished on Liebert Instant Online September 6, 2017 